Short Story

Canadian Journal of Family and Youth, 8(1), 2016, pp 239-242

ISSN 1718-9748 (C) University of Alberta

http://ejournals.library.ualberta.ca/index/php/cjfy

\title{
Diner on the Drag
}

Theresa Poirier

Sharon and her boyfriend Jake arrived in Vancouver in time for New Year's. But they weren't there to party. They were looking for Sharon's dad, Bernie. Sharon hadn't seen him since she was thirteen, when he went nuts. When he left her mother. That was six years earlier. Bernie was the quintessential Duddy Kravitz, who ended up homeless. Drugs, depression and greed led him to become the bearded man who walks in the middle of the street, causing chaos with his grocery cart brimming with rattling empties.

Scanning the sidewalk, Sharon said, "Pull over by that construction sign." Jake parked. Sharon got out. Shut the door. Jake lowered the window half way while she breathed through chapped lips, fogging up the outside of the passenger window. "What's the plan?" He asked.

She said, "Wait here. I'll be right back." Sharon had seen a couple sitting in a bus shelter, trying not to cut their lips on a bottle they shared between them. They didn't faze her. When she was younger, her father threw her out for hanging with gangs. They looked like bookends. His leather jacket stopped at his mid-section, but his cardigan hung to his knees, while the young woman's leather boots with their skeletal salt stain, wearing her yellow jacket, sat curled into him. His black hair too greasy to blow in the wind, stuck to the sides of his cheeks. She mirrored him, wearing a scarf but no tuque.

Walking to the bus stop, retrieving a ten and a snapshot from her wallet, Sharon asked, "Have you seen him, he's my dad I'd like to find him." 
Short Story

Jumping up the girl said, "Another ten and I'll tell you where to find him."

“Exactly?" Sharon asked.

"Yeah, exactly. No shit."

Pulling out another bill, Sharon asked, "Where?"

Shifting toward the door, the boy said, "He stands outside the subway at the same time each day."

"What time?" What station?" Sharon asked still holding on to the cash.

“Central, around two, it's just down maybe six blocks."

Sharon gave her the cash. Crawling into the truck, she looked at the time, then said, “Let's go to Timmy's. I saw one back on Hastings. We have to be at Central Station at two. They said he goes there every day."

"Really? "Jake said as he drove over potholes concealed by snow, watching the other drivers struggling to keep on the road. Snow is a disaster on the lower mainland. Driving's dangerous.

"We'll see, won't we?" She said.

They pulled off the road. Parked. They found a table by the window. Jake got them coffees. Sharon sat thinking about the girl's banana yellow jacket. The thought of banana reminded her of days wrapped in blankets and of children's medicine. She thought that she could smell the stench of the oil refineries. But turning her head she saw the same couple come for coffee. Sitting adjacent, they nodded in recognition. Noticing his bitten fingernails, Sharon looked at the girl's face to see that she had three freckles under the corner of her left eye.

Jake came with coffee. Gusts shook the window. The sight of snow blowing past the empty office towers being the frosted glass of a lamplight, gave her a chill. Shivering, she 
Short Story

remembered the way the scrapers created wind tunnels past City Center Mall, blowing snow in every direction. How Churchill Square ceases to smell like shit in the winter. And taking walks where sparrows nestled in milk jug bird feeders in the river valley, when it was so cold our nostrils froze shut.

"Hey, wait till we're outside!" The boy in the leather jacket bellowed. The girl squealed. Apparently she thinks that it is cute when she puts her cold hands on your neck.

Like a schizophrenic, she was tearing up the napkin into pieces as she talked about her coming exams. Then she said, 'I can't stand to wear white in winter, it makes me feel like I'm trying to look clean."

Sharon didn't want to hear anymore. Closing her eyes she pictured the four giant Christmas trees blinking on the face of the TELUS tower, which she could see from her bedroom window when she was little.

Jake sighed.

"What is it?"

"Nothing. I wondered if all the people in the glass windows actually make anything."

Pushing her chair back from the table, Sharon said, "It's time to go."

Arriving at two, they saw three men in high visibility clothing and work boots, filthy and laughing by the curb. Coming from behind the men, they saw a thin figure approaching the train station. He hunched and walked with a limp from boots that didn't fit. His frozen beard was matted and he smelled of Marlboro. He had frosted brown hair.

He recognized Sharon before her feet were on the ground. They bought him lunch at a nearby diner. He ate. A lot. She talked. Jake watched his thawing eyelashes warming while he ate. And at his teeth, which seemed to grow right out of his mustache as he spoke. He could 
Short Story

smoke cigarettes without them ever leaving his lips. They were talked out. Remembering his sweet tooth, Sharon ordered a whole pie for her dad to take. They said their goodbyes, then she watched him disappear into the streets.

Heading home, the road was rank with steam rising from the sewers. A tear fell from her face, when she said, "I wish I'd never found him. He's not my dad anymore. I'm going to remember him the way he was before we moved here, when his posture was fecund and proud. 